\title{
A Case Study of Topnotchers' Preparations and Contributory Attributes in Passing the Licensure Examination for Teachers
}

\author{
Richel P. Albite ${ }^{1}$
}

\section{Abstract}

This paper explores the Licensure Examination for Teachers' (LET) experience of Bachelor in Elementary Education (BEEd) topnotchers of the University of Southeastern Philippines (USeP) Tagum-Mabini. This qualitative single case study sought to determine topnotchers' preparations and attributes deemed contributory to successful topping of the LET. Data were obtained through interviews from the seven (7) purposively sampled participants who were the pioneering batches of LET topnotchers in the BEEd program, covering years 2011-2015. Semi-structured in-depth interviews (IDIs) were conducted to gather results for an information-rich case study. Qualitative data analysis was applied identifying emergent categories and themes based on participants' quotes excerpted from interview transcripts. Findings indicate that BEEd topnotchers' preparations consisted of the following: goal setting and knowing oneself; interest in reading and overlearning the material; being test-wise and understanding the nature of the LET; and attending a LET review program and committing to it. Five strong contributory attributes were also revealed such as: having metacognitive test-taking skill; strong faith in God;

1 The author is a faculty of the College of Teacher Education and Technology.

Contact the author at r.albite@usep.edu.ph 
good support system; solid foundation in college; and active participation in a study group. Majority of them expressed their College's (the College of Teacher Education and Technology) contribution and influence to their success through competency-based instruction, quality faculty and LET-type assessment. More intensive and extensive training and enhancement which focuses on the identified preparations and contributory attributes may be targeted to produce a common ground for effective teaching-learning practice for future graduates.

Keywords: licensure examination, teacher education, preservice teachers, topnotchers, exam preparations, topnotchers' contributory attributes

Licensure tests as key measures of quality control for entry into most professional careers are of global importance nowadays. A teacher education graduate must have a valid professional license to be employed and officially considered a Teacher.

There are two major reasons for teacher licensure tests. These are 1) to protect the public (as with most licenses), and 2) to make teacher training programs accountable for the initial academic competence of those who complete their programs (Stotsky, 2009).

In the Philippines, teacher licensure examination is facilitated by the Professional Regulation Commission through Board Licensure Examination for Teachers (LET) based on Republic Act No. 7836, otherwise known as the "Philippine Teachers' Professionalization Act of 1994". This is the nation's means to ensure and promote quality education by proper supervision and regulation of the licensure 
examination and professionalization of the practice of the teaching profession. Passing the licensure exam is very important in the field (Educational Testing Service, 2004); it does not just define the quality of teachers but also strengthens and improves the quality of teaching (Hertz \& Chinn, 2000).

There are separate examinations for elementary and secondary school teachers both having a common passing rate of 75 percent. The elementary level consists of two parts: professional education and general education, while field of specialization component is added to the secondary level (aside from professional and general education). Those who pass the LET board examination do not only gain honor and prestige but also have competitive edge over those who fail it (Pachejo \& Allaga, 2013).

In an article published in PBEd's (Philippine Business for Education) electronic site, Tan (2016) revealed that more than half of LET takers failed in 2014 although the performance of Teacher Education Institutions (TEIs) in LET “generally improved”. Since LET results have been taking much toll not just on the professional career of LET takers but also on the performance of the colleges of TEIs, it is important to explore the LET takers' preparation and contributory attributes. Also, since USeP Tagum is known as one of the LETperforming TEIs in the country, an interesting area to explore is on how its BEEd topnotchers were able to land in the much-coveted "topnotcher" spot. Thus, determining the extent to which LET performance can be credited to the aptitude and ability of these individuals as opposed to the preparation they received in college and how TEIs contributed to their graduates' performance on the licensure examination is worthy of scholarly investigation.

This study presents the topnotchers' preparations and contributory attributes in passing the LET. Not too many similar researches in such area have been conducted in the country, which strengthened the 
interest of the author to conduct the study. To consider not just LET passers but topnotchers' accounts and experiences particularly on how they prepared and performed during the LET could lead to sound recommendations for further pedagogical innovation. Results of this paper are deemed useful to the body of knowledge and to the delivery of both theoretical and practical implications in the area of licensure examinations and teacher education in general.

\section{Methodology}

This study followed the qualitative research method to get a better understanding of topnotcher participants' preparations and contributory attributes through first-hand experience, truthful reporting, and quotations of actual conversations with the participants. The qualitative research process involves emerging questions and procedures, data typically collected in the participants' setting, data analysis inductively built from particulars to general themes, and the researcher making interpretations of the meaning of the data (Creswell, 2007).

The case study approach was particularly employed in the research. This is to seek deep understanding of particular instances of phenomena (Mabry, 2008) and to develop detailed, intensive knowledge (Robson, 2002) about a case. This is a single case study that focuses on the batch of LET topnotchers 2011-2015 of the University of Southeastern Philippines (USeP) Tagum-Mabini Campus's College of Teacher Education and Technology (CTET) Bachelor of Elementary Education (BEEd) program. The units of analysis in this research are the preparations and contributory attributes of USeP topnotchers, while the units of observation (the unit on or from which data are collected) were the seven (7) USeP topnotchers who took the LET in their respective batches. The seven participants of the study were all BEEd 
pioneering topnotchers of the LET from CTET. Here are the ranks of the participants arranged chronologically: 5th place in the April LET 2011 ; 1st place in the September LET 2011; 7th place in the September LET 2012; 2nd place in the August LET 2014; and 6th, 9th and 10th places in the September LET 2015. They are considered the pioneering batch, since years after them subsequent rolls of topnotchers have been proclaimed (up to the present).

Data were supplied through in-depth interviews (IDIs). Each was audiotaped and transcribed for analyses. As suggested by Boyce and Neale (2006), the protocol is to begin with an introductory comment discussing duration and manner of interview and the opportunity for questions. Each IDI took an average of 60-90 minutes in convenient locations. They were semi-structured interviews conducted face-to-face. The interviews proceeded in a conversational manner but were guided by a set of questions previously validated by a pool of experts. Though prone to possible bias, IDI has the advantage of providing much more detailed information to elicit an information-rich case study than what is available through other data collection methods (Woods, 2003). Aside from the possibility of replication, it also provides a more relaxed atmosphere collecting information in a comfortable and conversational way. The interview protocol was designed to encourage participants to explain LET preparations and contributory attributes as they experienced them.

The researcher herself is one of the topnotchers, as a matter of fact, the very first topnotcher from the same program and College, but decided to exclude herself as participant of the study. She also served as one of the instructors of the more recent batches of topnotchers. By the time the data were collected for this research, she knew all the participants well. Given the qualitative nature of the study, these familiar relationships could be viewed as both strength and weakness. The 
researcher maintained an emic perspective as the study was conducted to avoid unnatural and controlled responses. This was carefully observed all throughout the research process ensuring that all accounts or narratives of the topnotchers are recorded, coded and saturated. Since the research involved collecting data from people about people (Punch, 2005), the researcher needed to protect her participants and so she provided them pseudonyms to ensure anonymity and confidentiality.

This study involved inductive analysis of data (Lincoln \& Guba, 1985), a qualitative technique consistent with the constant comparative method (Glaser \& Strauss, 1967). Interview transcripts and document review served as primary data sources for the analyses. These categories were then compared and contrasted to form more general themes that captured larger aspects of data. Having identified emergent categories and themes, data sets were looked back to identify specific excerpts that signalled these groupings to ground the analyses. The quotes provided throughout the discussion were excerpted from interview transcripts.

Given the qualitative nature of the analyses, discussion is embedded in the presentation of the results. Participants' reflections on their LET preparations were grouped into five overarching themes: goal setting, interest in reading, being test-wise, early preparation, and attending LET review program. In terms of contributory attributes, the following themes were revealed: being metacognitive test-takers, faith in God, support system, solid foundation in college, and being part of a study group.

In the presentation and discussion of results in the succeeding section below, participants' narratives are used (this is a means in the qualitative inquiry to show acceptability and replicability of themes). Several, if not all, of these excerpted answers are candid and expressed liberally. All of the patterns identified and discussed emerged from the comments of at least four of the seven participants. 


\section{Results and Discussion}

Presented in this section are the analysis of data, interpretation, and implications of the findings. All these were meant to answer the overarching research question: What are the topnotchers' preparations and contributory attributes in passing the Licensure Examination for Teachers?

\section{Preparations of LET Topnotchers}

Participants shared the common factors used or applied during review for the LET. These factors were: goal-setting and knowing oneself; interest in reading and overlearning the material; being test-wise and understanding the nature of the LET; early preparation while still an education student; and, attending a LET review program, final coaching and committing to it. Several of the participants expressed how important it is 'knowing oneself especially one's strengths and weaknesses, having a study preference, and possessing the right attitude while still in the LET preparation journey.

Goal setting. Being self-motivated, the participants claimed that it is important to set a goal and base it on one's capacity. For them, taking the LET should be a 'one-shot' challenge. Hopeful, the participants pursued the goal with determination and high level of introspection. However, it is worth-mentioning that even when all of them were self-motivated at that time, most of them only set the goal of 'just passing' and 'not topping' the board exam. This was confirmed by one participant who said that he thought only of passing the examination. He found the items 'easy' in general, yet he did not consider the possibility of claiming a spot in the top 10. Norm-referencing - or a measure of performance in terms of an individual's standing in some known group - is manifested on ranking, as can be derived from this example. 
Another participant revealed how she pushed herself to reach a particular percentage score during reviews. Having the knowledge that 75 percent is the passing percentage in the LET, she shared:

I set a goal for myself like a particular score every time I answer drills. It must be 85\%! 85 over 100. My goal must be $85 \%$ in every drill whether intensive self-review or review at the review center. (Participant 7)

This particular finding concurs with the study of Cortez, Alipante and Lajato in 2017 regarding how the emotional domain, and not just the cognitive, could be a significant predictor in passing the LET.

Further, it is to be noted that among these seven pioneering topnotchers, only two of them were honor graduates or cum laude in their respective batches. This particular finding goes against the results of other studies which claimed that college Grade Point Average (GPA) significantly affects performance in LET (Quiambao, Baking, Nuqui \& Cruz, 2015; Hena, Ballado, Dalucapas, Ubane \& Basierto, 2014; Pascua $\&$ Navalta, 2011). From the interviewed participants, it is revealed however that proper goal-setting including the conscious effort to learn more can contribute to LET success. Given this, holistic preparation especially mind-setting should be considered in preparing Education graduates as they take the board examination.

Interest in reading. The research participants deemed reading as an indispensable tool to learn and re-learn concepts. Their motivation further led them to sustain reading all the materials they compiled from college including borrowed review materials from friends who had already been LET passers. They found it beneficial that, together with their set goals, reading those materials was not just educational but also entertaining and relaxing. However, they emphasized that the activity of reading as part of LET preparation must be intentional. In order to overlearn the material, they said they went beyond normal reading, that 
is, they built connections among concepts, synthesized information through a graphic organizer, used schema, and applied self-monitoring and understanding. These strategies are consonant with what Hoyt mentioned in 1999 as follows: visualizing, determining importance, making inference (prediction and summary), and using fix-up strategies.

Let us take for example this one participant sharing about her enthusiasm for reading:

I read the materials throughout the day! I should say you must know basic theories and methods. I overlearn the material. When I answer Biology drills, I set an 18/20 score. If I don't get that, I reread the material up to the point of owning the information. I should be well-read... As what Louis Pasteur said, "chance favors only the prepared mind'. Luckily, I read fast. I can comprehend easily which was good. I advise it to my students now. Read! Read! Read! Without my love for reading, I don't know how I would've succeeded in taking the LET. (Participant 5)

The above example shows the participants' awareness of their metacognitive skills and how they maximized the quality of their reading time. This yearning for knowledge through reading is in consonance with the attributes set by the Philippine Professional Standards for Teachers (PPST) particularly in regards to having the ability to recognize the importance of mastery of content knowledge and its interconnectedness within and across curriculum areas (D.O. No. 42, 2017). Hence, reading has to be a significant factor in the LET takers' preparation.

Beingtest-wise. Participants applied deductive strategies in taking the LET, including eliminating options and using content information from the stem or other information given in the test. (Deductive strategies are part of a taxonomy of test-taking strategies developed by Millman and Paulk in 1969). The participants had been made familiar with the use of 
words 'always', 'all' and other determiners that are most likely incorrect responses in an item. According to one participant:

In answering multiple choice items, the first technique I applied was to understand the question, know what it asked. After you do that, you can then easily eliminate those options you thought we are not the correct ones. Of course, you have to look for the key terms in the stem then I recall in which subject I encountered it. For example, if it's a teaching methodology, I recall and eliminate options not related to it. And if ever I don't understand the question, I take advantage of its options. I can easily detect those options with the same idea then I eliminate them coz it can't be that either of them would be the key (correct answer). I used those techniques when I answered our LET. (Participant 7)

Test-wiseness is evident in the above statement. Managing and strategizing on every item helped the participants during the examination. Similarly, a clear grasp of test constructors' governing philosophy in writing situational test items became another participant's advantage:

What's real is different from what's ideal and LET is very much leaned on the idealistic view. I kept on emphasizing to my co-LET takers that we have to be 'idealistic' when we answer LET test items. It has to be the ideal ones especially on situational items; that's how you should choose the correct answer. (Participant 3)

In answering classroom management-related test items, it appears that one should have a good sense of what is 'ideal' from what is 'real' especially with regard theory-based situational items, as expressed by the participant above.

It is as well of good fortune for these batches of graduates to know how LET-based type of test items especially in Professional Education courses is integrated in their summative assessment even during their 
pre-service training in the College. The practice has indeed reaped its benefits. Having knowledge on how to ace multiple choice tests has contributed to eliminating test anxiety before and during taking the board examination. Such findings regarding test-wiseness affirm the study of Cortez, Alipante and Lajato (2017) on the cognitive, emotional and physical aspects of teacher education graduates.

Early preparation. Nothing beats a prepared individual. That was the collective realization of the LET topnotchers; they recognized that the LET they took and topped was an achievement not just of the teacher education curriculum but even of their basic elementary and secondary education. Thus, when asked about their advice to future LET takers, they were unanimous in saying that LET takers should prepare early. More to that, the participants urged those interested in joining the teaching force to start preparing for the LET the earliest possible time. As a matter of fact, when asked when in particular to start preparation, this participant remarked:

The preparation should not only start the moment you decide to take the LET. It should be while you're still at school studying the program. You must be prepared... (Participant 5)

Another asserted:

I should say, my preparation started when I was still in elementary... (as if) I assessed the accumulated learning I got in elementary, high school and college. But better if you still review for the LET aside from relying on your previous learning. (Participant 1)

Such statements show how critical readiness is, not just covering the LET schedule but even several years prior. It is worth-mentioning, additionally, that preparedness combined with taking the LET as a 
fresh graduate helps boost confidence of LET takers. Figuerres (2013) has in fact found out in a study she conducted on the University of Northern Philippines' teacher education programs that fresh graduates tend to perform better in the LET compared to those who took the later schedule. An early study of Catura in 2007 (cited in Corpuz, Faltado \& Mayordomo, 2014) had also revealed how inversely related age is with the LET performance of a graduate. Hence, first takers or younger graduates have better chances of passing the LET.

Attending LET review program. Majority of the research subjects enrolled in LET review centers. One enrolled in the in-house review center of the University's mother college (the College of Education in USeP's Obrero campus) while the rest enrolled in various private review centers in Davao City. When asked how attending a LET review program helped exam takers, one participant said:

It's important that you attend review sessions. If you rely on your own, you can do what you please, you can procrastinate. It demands much of your self-discipline. If you are in a review center, you are compelled to attend regularly. Someone would check our attendance, give us inputs (the coaches), refresh our memory, share to us more review materials... (Participant 1)

Aside from sticking to a strict routine and reviewing the principles and concepts of the exam, another point was stressed by a research participant:

I grabbed the opportunity to enroll in a review center. I need to learn the techniques and strategies, how to do the shading, how to fill up the form... At least there's someone to brief me and condition my mind on what to do. For that, I took a one-week leave from my work for 
the final coaching, Monday to Friday, a week before the exam. I benefited from it especially on how to rationalize the answers. (Participant 6)

This result supports previous studies that investigated factors affecting LET performance of Education graduates. One of the factors pointed out was attendance in LET review (Amparo, 2012). Visco (2015) likewise confirmed that licensure exam review is a good LET performance predictor. Not all though agree: Dagdag, Sarmiento and Ibale (2017) claimed that course audit review and licensure examination are not significantly associated with all aspects of the LET.

As regards having in-house review centers, various studies have mentioned that these review programs are effective in increasing test takers' probability in passing the board exam. As a matter of fact, TEIs establish their own in-house review centers. One of these TEIs is the University of the Cordilleras. Part of its program is to conduct mock board examination to trace the weakness of the examinees and to analyze their performance (Montemayor, Roxas \& Panayon, 2009). Imitating the actual exam, its College of Education faculty organized a comprehensive/mock board exam for its Bachelor of Science in Basic Education graduates and found out that respondents gained positive impact as revealed from an assessment of their performance. Thus, recommended was to continually facilitate mock exams to its graduates before taking the LET.

\section{Contributory Attributes}

There are five characteristics identified as contributory attributes to being a topnotcher which surfaced in the interviews. These are using metacognition skills, strong faith in God, good support system, solid foundation in college, and active participation in a study group. 
Using metacognition skills. Metacognition is defined as "thinking about thinking" which makes individuals monitor and control their thought (Martinez, 2006). Being related to motivation, it has two components: metacognitive knowledge and metacognitive regulation.

Metacognitive knowledge involves knowledge about oneself as a learner and some factors that may impact performance (declarative); knowledge about strategies (procedural); and knowledge about when and why to use strategies (conditional). Here is how metacognitive knowledge became evident for this participant:

I know where I'm good at and how to improve further. Sometimes, when I studied, I used mnemonics, acronyms like RRVOC, and I mentally arranged it together with other concepts. Once arranged in my mind, I can easily locate it... That's it, that's who I am. I always exert effort in almost everything I do. I am not complacent. I have to memorize, master the concepts so that when I'm asked the next time, I can correctly answer. Up to the littlest detail, I have to comprehensively master it. (Participant 7)

On the other hand, metacognitive regulation is the monitoring of one's cognition, which includes planning of activities, awareness of comprehension, and evaluation of the efficacy of monitoring processes and strategies (Schraw, Crippen \& Hartley, 2006).

The participants deliberately applied these specifics of metacognition while preparing for the examination. Some of them decided to focus solely on the review, while others chose to work and review at the same time. To those who were working while reviewing, they took a month- or week-long leave from work to attend the final coaching in Davao City. This experience was described by Participant 7:

I started feeling like it has no point. Going home at night (from work) feeling tired and could't review, I felt more 
helpless. I was afraid that I didn't have much time left, then I decided to take a break from my job and from then on, I started my 'intensive' review.

This response shows the importance of setting priorities and planning activities in attaining a goal in spite of a challenging task. It confirms the findings of Mayuga (2016) on the significant relationship between LET performance and the learning skills preservice teachers gained during their field study. Since teaching entails much decision making - before, during and after instruction (Rowan, 1997) - Education graduates have to be capable of applying the same when reviewing for the LET.

Strong faith in God. All of the participants believed faith has contributed to their success. 'Faith (in God) can move mountains,' as was mentioned. This is a finding worthy to be highlighted as it was not an identified factor by some reviewed researches (Pascua \& Navalta, 2011 and Goldhaber \& Hansen, 2010 only identified among the personal factors the following: profile of respondents, level of motivation, gender, race and career preferences).

This attribute of having faith in God is attested to by one participant:

Of course, we know our capacity. We know our highest limit, up to where our ability can reach. At that time, I know I could pass the exam but it did not stop me from continually asking and praying for God's intervention that hopefully I could be one of the topnotchers. I prayed that at least He could consider me even in the last spot. If not, then at least the Lord could give me the heart to accept whatever possible result (the LET) could bring. All things work together for good. I'm just thankful that He never failed me. (Participant 1 ) 
Supporting this idea, Abulon in 2014 revealed that being spiritual is one of the inherent characteristics that could facilitate effective teaching in basic education. Other variant inherent characteristics are being flexible, humble, open-minded, sincere, energetic, self-confident and honest.

Good support system. Another values-based attribute that surfaced in the interview refers to the support system the LET takers received from their family and friends. When asked to whom they owe their being topnotchers, all of them mentioned these members of their support system. Specifically, the financial, moral and spiritual support they received increased their confidence and self-efficacy including this participant who mentioned about being spared from domestic work at home:

My parents played a significant role in my LET success. My mother was very considerate with my review schedule. She exempted me from my laundry chores! I personally asked my mother for that favor. (Participant 7)

Shulman, Zeichner, Knight, Fessler, Crow and Johnston (2000) have identified parental assistance as having significant high positive correlation and significant predictor to passing a teacher's licensure examination. Indeed, aside from admission test, degree course, English proficiency and institutional passing rate of education graduates (Pascua \& Navalta, 2011; Wenglinsky, 2000), one more contributory factor is good support system extended by people in the surrounding environment.

Solid foundation in college. One of the participants provided evidence to this attribute:

We can attribute it to USeP as well. There, we were not spoonfed. We were trained to be active in the class. In times 
of reporting, we had to do research for additional inputs in our report. We had to scan other references aside from the books we read. That was why when we're enrolled in the review center, it was just a 're-view' of our previously encountered concepts and principles. Everything was almost familiar to us already. (Participant 2)

It can likewise be said that the College's high level of passing rate in the previous batches of LET passers might have served as influential factor to their success. It is worthy to note that the College of Teacher Education and Technology (under which is the BEEd program) has its 'mother college' in USeP-Obrero, which is the College of Education. The mother college was awarded Center of Excellence (COE) in Teacher Education in 2010. Thus, living up to the standards, USeP Tagum BEEd graduates have to strive and demonstrate excellence in the LET.

As what is claimed in similar studies (such as by Fallado 2014 who said that LET performance could be predicted by three factors: admission and retention policy, curriculum and instruction and faculty competence), licensure examination results truly reflect the foundation and internal efficiency of the educational system.

As shown, passing the LET can be shaped by educational influences as well. Academic performance in General Education, Professional Education and Specialization serves as strong determinants of Board Examination Performance (Pascua \& Navalta, 2011; Garcia, 2010; Figuerres, 2010). Thus when problems such as curriculum misalignment happens, Education graduates could lose motivation, interest and determination in the exam (Pachejo and Allaga, 2013).

For this purpose, CTET continually upgrades its curricular offering in consonance with the Philippine Professional Standards for Teachers (PPST) formerly the National Competency-Based Teacher Standards (NCBTS) (D.O. No. 32, 2009). 
Active participation in a study group. Participants claimed that they benefited from a study group during LET review period, as evidenced by this narrative:

I had a study group before with my co-teachers. We spent 2 to 3 hours every afternoon brainstorming. We also did 40 item pre-test as if we're in a review center. Then we checked our answers to see who got the highest score. I was proud every time I got highest (and) sometimes it's my co-teacher. (Participant 6)

Turner (1995) explained that collaboration among members in a study group provides opportunities for them to experience disequilibrium, which could ignite their curiosity and interest on the topic being studied. Moreover, it is a venue for peer modeling, which could motivate members for a successful performance. Working in a study group promotes academic engagement through the added responsibility of group performance with longer persistence at challenging tasks.

Considering the fact that teaching profession has its social dimension, having as well good interpersonal relations with colleagues reinforces this dimension. Forming a study group implies smooth interpersonal relationships which is a manifestation of good teaching imbued in a cultural Filipino concept as "asal" (Bustos-Orosa, 2008). 


\section{Conclusion}

Aiming to explore the LET experience of BEEd pioneering topnotchers, preparations and positive attributes do contribute to success in the LET board examination. The teacher education program provided by the College of Teacher Education and Technology to its graduates has exhibited curriculum effectiveness (competency-based instruction, quality faculty, LET-type assessment) based on these participants' top performance (not simply passing performance) in the LET. Since the quality of teaching is usually noted to be the topmost important factor affecting student learning outcomes, it can be concluded that preparations and contributory attributes must be targeted too in order to produce effective teaching-learning practice for the College's future graduates. 


\section{References}

Abulon, E. (2014). Basic Education Teachers' Concept of Effective Teaching: Inputs to Teacher Education Curriculum in the Philippines. International Journal of Research Studies in Education. 3(3). 35-48. doi: 10.5861/ijrse.2014.723

Amparo, R. (2012). "Gaining insight into teaching: the lived experiences of Teachers of the Year," Florida International University, pp. 1-10,

Boyce, C. \& Neale, P. (2006). Conducting in-depth interviews: A guide for designing and conducting in-depth interviews for evaluation input. Pathfinder International, 2, 5-16.

Bustos-Orosa, M. (2008). Inquiring into Filipino teachers' conceptions of good teaching: A qualitative research study. The Asia-Pacific Education Researcher, 17(2), 157-171.

Corpuz B., Faltado III, R., \& Mayordomo, J. (2014). Performance of education graduates in the licensure examination for teachers. PAFTE Research Journal, Quezon City, Philippines: Adriana Printing Co., Inc.

Cortez, M., Alipante, A., \& Lajato, D. (2017). Binary logistic model on factors affecting the result of licensure examination for teachers (LET). International Journal of Education and Research, 5(5), 279-288

Creswell, J. (2007). Qualitative inquiry and research design: Choosing among five approaches (2nd ed.). Thousand Oaks, CA: Sage

Dagdag, J., Sarmiento, C. \& Ibale, J. (2017). Examining the Factors of Licensure Examination for Teachers Performance for Program Strategy Enhancement. Asia Pacific Journal of Multidisciplinary Research, 5(4), 34-39. doi: 10.13140/RG.2.2.13530.18889 
DepEd. (2009). DO 32, s. 2009 - National Adoptation and Implementation of NCBTS-TSNA and IPPD for Teachers, and Integration of Its System Operations in the Overall Program for Continuing Teacher Capacity Building. Retrieved July 7, 2019 from http://www.deped.gov. ph/sites/default/ files/order/2009/DO_ s2009_32.pdf

DepEd. (2017). DO 42, s. 2017 - National Adoptation and

Implementation of the Philippine Professional Standards for Teachers. Retrieved July 8, 2019 from http://www.deped.gov.ph/ orders/do42-s-2017

Educational Testing Service (2004). Where we stand on teacher quality. Retrieved on July 8, 2017 from https://goo.gl/B9BZCP

Faltado, R. (2014). Correlates of performance in the licensure examination of selected public and private teacher education institutions. International Journal of Education and Research, 2(8), 167-176.

Figuerres, O. (2010). An Analysis of the Performance of the University of Northern Philippines in the Licensure Examination for Teachers. International Journal of Educational Research and Technology. Retrieved from www.soeagra.OriginalArticle.com/ ijert/ijert.htm

Figuerres, O. (2013). Analysis on the performance of University of Northern Philippines in licensure examination for teachers. International Journal of Scientific and Research Publications, 6(1), 455-461.

Garcia, G. (2010). Academic Performance as Determinant to Pass the Licensure Examination for Teachers. International Journal of Educational Research and Technology. Retrieved from www.soeagra. OriginalArticle.com/ijert/ijert.htm

Glaser, N. \& Strauss, A. (1967). The Discovery of Grounded Theory: Strategies for Qualitative Research, Chicago: Aldine Publishing Company. 
Goldhaber, D. \& Hansen, M. (2010). Race, Gender, and Teacher Testing: How Informative a Tool is Teacher Licensure Testing? American Educational Research Journal, 47(1) 218-251. doi: 10.3102/0002831209348970

Hena, R., Ballado R., Dalucapas, M., Ubane, S., \& Basierto, R. (2014). Variates of the performance of teacher education graduates in the licensure examination for teachers (LET). International Journal of Interdisciplinary Research and Innovations, 2(4), 157163.

Hertz, N. \& Chinn, R. (2000). Licensure examination. Retrieved on February 16, 2017 from https://goo.gl/zJwbMi

Horn, F. (1999). "Regression Model for the National Teacher Examination." Journal of Education for Effective Teaching. 48(34), 22.

Hoyt, L. (1999). Revisit, Reflect, Retell: Strategies for Improving Reading Comprehension. Portsmouth, NH: Heinemann.

Lincoln, Y. \& Guba, E. (1985). Naturalistic Inquiry. Beverly Hills, CA: Sage.

Mabry, L. (2008). Case study in social research. The SAGE handbook of social research methods. P. Alasuutari and L. Bickman (eds.). Los Angeles \& London: SAGE.

Martinez, M. (2006). What is metacognition? Phi Delta Kappa, 87(9), 696699. doi: 10.1177/003172170608700916

Mayuga, V. (2016). Field study courses and internship as practical work approach: determinants of LET performance. E-Proceedings of the 3rd International Conference on Language, Innovation, Culture, and Education, pp. 74-86.

Millman, J. \& Paulk, W. (1969). How to Take Tests. New York: McGraw Hill 
Montemayor, E., Roxas, C. \& Panayon, V. (2009). Mock Examination: Its Influence on the Performance in the Licensure Examination for Teachers. University of the Cordilleras Research Journal, 1(3), doi:10.1.1.683.2543

Pachejo, S, \& Allaga, W. (2013). Academic Predictors of the Licensure Examination for Teachers' Performance of the Rizal Technological University Teacher Education Graduates. International Journal of Educational Research and Technology, 4(4) 31-40.

Pascua, J. \& Navalta, J. D. (2011). Determinants of LET Performance of the Teacher Education Graduates in a State University. JPAIR Multidisciplinary Research Journal, 6(1), 90-102. Retrieved from https:/ / ejournals.ph/article.php?id $=7472$

Punch, K. (2005). Introduction to social research: Quantitative and qualitative approaches (2nd ed.). London: Sage.

Quiambao, D., Baking, E., Buenviaje, L., Nuqui, A., \& Cruz, R. (2015). Predictors of board exam performance of the DHVTSU college of education graduates. Journal of Business \& Management Studies, 1(1), $1-4$.

Robson, C. (2002). Real world research: A resource for social scientists and practitioner-researchers. Oxford: Blackwell.

Rowan, B. (1997). Comparing Teachers' Work with Work in Other Occupations: Notes on the Professional Status of Teaching. Educational Researcher. 23(6), 4-17.

Schraw, G., Crippen, K., \& Hartley, K. (2006). Promoting self-regulation in science education: Metacognition as part of a broader perspective on learning. Research in Science Education, 36, 111-139. doi: 10.1007/ s11165-005-3917-8 
Shulman, T., Zeichner, K., Knight, Z., Fisher, J., Crow, F., \& Jhonston, P. (2000). Current Empirical Researches on Prospective Teachers. New York: Teachers College Press, 2000.

Sicat, R. (2000). Concerns of Teacher Education. The Educators. 17(3). 22.

Stotsky, S. (2009). Licensure Tests for Special Education Teachers:

How Well They Assess Knowledge of Reading Instruction and Mathematics. Journal of Learning Disabilities, 42(5), 464-474. https:/ / doi.org/10.1177/0022219409338740

Tan, C. (2016) "Impact of review on the performance of graduates in the Licensure Examination for Teachers, 2012 - 2014," e-Proceedings of the 4th Global Summit on Education, pp. 64-73

Turner, J. (1995). The influence of classroom contexts on young children's motivation for literacy. Reading Research Quarterly, 30(3), 410-441.

Visco, D. (2015). Predictors of performance in the licensure examination for teachers of the graduates of higher education institutions in Abra. International Journal of Management Research and Business Strategy, 4(1), 181-191

Wenglinsky, H. (2000). Teaching the Teachers: Different Settings, Different Results. Princeton, NJ: The Educational Testing Service.

Woods, M. (2003). Interviewing for research and analysing qualitative data: An overview. School of Health and Social Sciences. Massey University. 